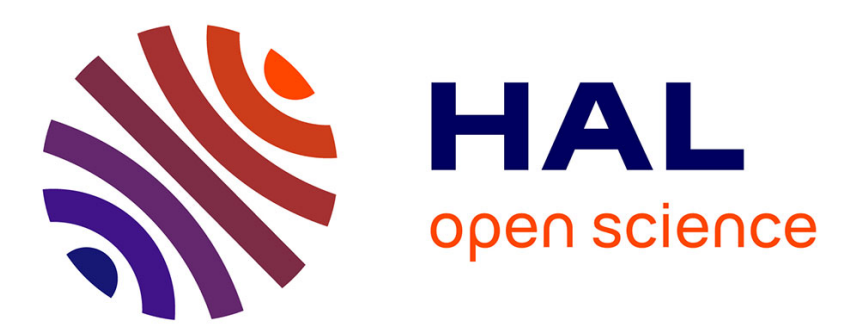

\title{
FeII induced mineralogical transformations of ferric oxyhydroxides into magnetite of variable stoichiometry and morphology
}

Muhammad Usman, Mustapha Abdelmoula, Khalil Hanna, Brian Grégoire, Pierre Faure, Christian Ruby

\section{To cite this version:}

Muhammad Usman, Mustapha Abdelmoula, Khalil Hanna, Brian Grégoire, Pierre Faure, et al.. FeII induced mineralogical transformations of ferric oxyhydroxides into magnetite of variable stoichiometry and morphology. Journal of Solid State Chemistry, 2012, 194, pp.328-335. 10.1016/j.jssc.2012.05.022 . hal-00845705

\section{HAL Id: hal-00845705 \\ https://hal.science/hal-00845705}

Submitted on 17 Jul 2013

HAL is a multi-disciplinary open access archive for the deposit and dissemination of scientific research documents, whether they are published or not. The documents may come from teaching and research institutions in France or abroad, or from public or private research centers.
L'archive ouverte pluridisciplinaire HAL, est destinée au dépôt et à la diffusion de documents scientifiques de niveau recherche, publiés ou non, émanant des établissements d'enseignement et de recherche français ou étrangers, des laboratoires publics ou privés. 
$1 \quad \mathrm{Fe}^{\mathrm{II}}$ induced mineralogical transformations of ferric oxyhydroxides into magnetite of variable stoichiometry and morphology

3

${ }^{a}$ Laboratoire de Chimie Physique et Microbiologie pour l'Environnement, LCPME, UMR 7564, 7 Institut Jean Barriol, CNRS-Université de Lorraine, 405 rue de Vandoeuvre, 54600, Villers-lès-Nancy, France.

b Géologie et Gestion des Ressources Minérales et Energétiques, G2R UMR 7566, CNRS-Université de Lorraine, BP 239, 54506, Vandoeuvre-lès Nancy, France.

${ }^{\mathrm{c}}$ Ecole Nationale Supérieure de Chimie de Rennes, UMR CNRS 6226 "Sciences Chimiques de Rennes", Avenue du Général Leclerc, 35708 Rennes Cedex 7, France.

\section{* Corresponding author:}

17 LCPME, 405 rue de Vandoeuvre, 54600, Villers-lès-Nancy, France.

18 Tel: + 33383685220

19 Fax: + 33383275444

20 Email: christian.ruby@lcpme.cnrs-nancy.fr

\# Present Address: Institute of Soil and Environmental Sciences, University of Agriculture, 23 Faisalabad, Pakistan 
26 The Mössbauer spectroscopy was used to monitor the mineralogical transformations of 27 ferrihydrite $(F)$, lepidocrocite $(\mathrm{L})$ and goethite $(\mathrm{G})$ into magnetite as a function of aging time. 28 Ferric oxyhydroxides were reacted with soluble $\mathrm{Fe}^{\mathrm{II}}$ and $\mathrm{OH}^{-}$in stoichiometric amountsto 29 form magnetite at an initial $\mathrm{pH}$ of $\sim 9.7$. Observed transformation extent into magnetite 30 followed the order: $\mathrm{F}>\mathrm{L}>\mathrm{G}$ with almost $30 \%$ of untransformed $\mathrm{G}$ after 1 month. The 31 departure from stoichiometry, $\delta$, of magnetite $\left(\mathrm{Fe}_{3-\delta} \mathrm{O}_{4}\right)$ generated from $\mathrm{F}(\delta \sim 0.04)$ and $\mathrm{L}(\delta$ $32 \sim 0.05)$ was relatively low as compared to that in magnetite from $G(\delta \sim 0.08)$. The analysis 33 by transmission electron microscopy and BET revealed that generated magnetite was also 34 different in terms of morphology, particle size and surface area depending on the nature of 35 initial ferric oxyhydroxide. This method of preparation is a possible way to form nano-sized 36 magnetite. 


\section{INTRODUCTION}

41

Iron oxyhydroxides are abundant in the environment and influence the biogeochemical cycling and availability of elements. In soils and sediments, iron oxides and oxyhydroxides are commonly found as ferric minerals like goethite, ferrihydrite, hematite and lepidocrocite with different characteristics such as crystallinity, stability, specific surface area and reactivity $[1,2]$.Due to their high specific surface area, iron oxyhydroxides act as important sorbents for dissolved species. They strongly influence the transport and availability of various nutrients (e.g., C, N, and P) [1, 2] and the mobility of organic and inorganic contaminants [3, 4]. In reduced soil zone, they exist as mixed $\mathrm{Fe}^{\mathrm{II}}-\mathrm{Fe}^{\mathrm{III}}$ compounds such as fougerite, the mineral counterpart of the $\mathrm{Fe}^{\mathrm{II}}-\mathrm{Fe}^{\mathrm{III}}$ green rust or magnetite $\left(\mathrm{Fe}^{\mathrm{II}} \mathrm{Fe}^{\mathrm{III}}{ }_{2} \mathrm{O}_{4}\right)[5,6]$. Due to the presence of structural $\mathrm{Fe}^{\mathrm{II}}$, magnetite is considered as reactive and is involved in the reductive transformations of inorganic [7] as well as organic pollutants [3, 8].

Magnetite can be synthesized in laboratory by various biotic and abiotic pathways. Formation of biogenic magnetite was reported as a result of microbial reduction of iron oxyhydroxides [9-12]. Abiotic procedures to form magnetite include partial oxidation of hydroxylated $\mathrm{Fe}^{\mathrm{II}}$ solution [13] or co-precipitation of $\mathrm{Fe}^{\mathrm{II}}$ and $\mathrm{Fe}^{\mathrm{III}}$ salts in aqueous solutions [14]. Magnetite can also be formed by interactions of ferric minerals with aqueous $\mathrm{Fe}^{\mathrm{II}}$ that induce their structural modifications and bulk phase transformations. These solid state transformations are controlled by various factors like molar ratio $x\left(\mathrm{Fe}^{\mathrm{II}}\right)=\mathrm{Fe}^{\mathrm{II}} /\left[\mathrm{Fe}^{\mathrm{II}}+\mathrm{Fe}^{\mathrm{III}}\right][15-18], \mathrm{pH}[18,19]$, anionic media [20], $\mathrm{OH}^{-} / \mathrm{Fe}$ ratio $[17,21]$ and structure of initial iron oxyhydroxide substrate [22]. The interaction of iron oxides with aqueous $\mathrm{Fe}^{\mathrm{II}}$ may lead to their transformations into ferric and/or mixed $\mathrm{Fe}^{\mathrm{II}}-\mathrm{Fe}^{\mathrm{III}}$ phases. Due to its poor cristallinity, solid state transformations of ferrihydrite are more widely reported. In the presence of low concentration of $\mathrm{Fe}^{\mathrm{II}}$ species, ferrihydrite was transformed either into goethite [14, 18-20, 23], lepidocrocite [18, 20, 22] or 
64 hematite $[18,24]$. At high $\mathrm{Fe}^{\mathrm{II}}$ amount, mixed $\mathrm{Fe}^{\mathrm{II}}-\mathrm{Fe}^{\mathrm{III}}$ minerals such as magnetite [15-18, $6522,25]$ or green rust $[17,26]$ were formed from ferrihydrite or lepidocrocite. But, formation

of magnetite from goethite by $\mathrm{Fe}^{\mathrm{II}}$ induced transformations has not been reported yet probably because of its higher thermodynamic stability. Also a comparative quantification of magnetite formation by using stoichiometric conditions from various ferric oxyhydroxides versustime has seldomely been performed. In this study, Mössbauer spectroscopy was used to determine the transformation extent of ferric oxyhydroxides when reacted with hydroxylated $\mathrm{Fe}^{\mathrm{II}}$ species in stoichiometric quantities to form magnetite. Mössbauer spectroscopy is a potentially useful tool for an accurate quantitative determination of the relative proportions of magnetite and remaining ferric oxyhydroxides. A special attention was devoted to determine the evolution of stoichiometry during transformation by determining $\mathrm{Fe}^{\mathrm{II}}$ and $\mathrm{Fe}^{\mathrm{III}}$ contents in magnetite structure where nonstochiometric compound can be written $\mathrm{Fe}_{3-\delta} \mathrm{O}_{4}$ [7, 27]. Indeed, the reactivity and stability of magnetite is dictated partly by its stoichiometry defined by $x=$ $\mathrm{Fe}^{\mathrm{III}} /\left(\mathrm{Fe}^{\mathrm{II}}+\mathrm{Fe}^{\mathrm{III}}\right)$ where $0.67 \leq x \leq 1$, with stoichiometric magnetite $(x=0.67$ or $\delta=0)$ being the most reactive composition [7]. It was shown that stoichiometric magnetite had a lower reduction potential than that of non-stoichiometric magnetite, consistent with higher reactivity toward pollutants such as nitrobenzene compounds [7].

Experiments were conducted on three different iron oxyhydroxides including ferrihydrite, lepidocrocite and goethite. Their transformation extent into magnetite was quantified as a function of aging time (1 hour, 1 day and 1 month). Morphological properties of initial and final products were determined by transmission electron microscopy and multipoint $\mathrm{N}_{2}$ BET analyses.

\section{EXPERIMENTAL SECTION}

\subsection{Sample preparation}




\subsubsection{Initial ferric oxyhydroxides substrates}

89

Experiments were conducted with three synthetic iron oxyhydroxides: 2-line ferrihydrite $(\mathrm{F})$, lepidocrocite $(\gamma-\mathrm{FeOOH})(\mathrm{L})$ and goethite $(\alpha-\mathrm{FeOOH})(\mathrm{G})$. The 2-line ferrihydrite $(\mathrm{F})$ was synthesized according to the method of Schwertmann and Cornell [28]. It was prepared by neutralizing a $0.2 \mathrm{M}$ ferric chloride solution with $1 \mathrm{M} \mathrm{NaOH}$ to a $\mathrm{pH}$ of around 7.5. The lepidocrocite sample $(\gamma-\mathrm{FeOOH})$ was synthesized by vigorous air oxidation of the $(0.228 \mathrm{M}$ $\mathrm{FeCl}_{2} \cdot 4 \mathrm{H}_{2} \mathrm{O}+0.4 \mathrm{M} \mathrm{NaOH}$ ) aqueous mixture under a constant neutral pH adjustment [28]. All the Fe $\mathrm{F}^{\mathrm{III}}$ precipitates were washed several times to remove electrolytes, centrifuged and then dried. The goethite $(\mathrm{G})$ sample was prepared by air oxidation of a hydrolyzed $\mathrm{FeSO}_{4}$ solution following a procedure described by Olowe et al. [29].

\subsubsection{Transformation experiments}

The mineralogical transformations of synthetic ferric oxyhydroxides were examined in batch experiments at room temperature $\left(20 \pm 1{ }^{\circ} \mathrm{C}\right)$. To ensure the exclusion of $\mathrm{O}_{2}$, experiments were conducted in glove box, an anoxic chamber $\left(\mathrm{N}_{2}: \mathrm{H}_{2}=98: 2\right)$. Stoichiometric magnetite $\left(\mathrm{Fe}^{\mathrm{II}} \mathrm{Fe}^{\mathrm{III}}{ }_{2} \mathrm{O}_{4}\right.$ ) contains the $\mathrm{Fe}^{\mathrm{II}}$ : $\mathrm{Fe}^{\mathrm{III}}$ ratio of $1: 2$, so the quantities of ferric oxyhydroxide $\left(\mathrm{Fe}^{\mathrm{III}}\right)$ and $\mathrm{Fe}^{\mathrm{II}}$ were chosen accordingly. Firstly, a suspension of $\mathrm{Fe}^{\mathrm{III}}$ oxyhydroxide was prepared (100 $\mathrm{mM}$ as $\mathrm{Fe}^{\mathrm{III}}$ molar concentration) and purged for 1 hour with filter-sterilized $\mathrm{N}_{2}$ (99.99\%) in order to ensure the evacuation of dissolved oxygen which is known to rapidly oxidize $\mathrm{Fe}^{\mathrm{II}}$ in the presence of oxides at circumneutral $\mathrm{pH}$ [30]. The reaction was started by adding $\mathrm{FeSO}_{4} .7 \mathrm{H}_{2} \mathrm{O}$ with $\mathrm{Fe}^{\mathrm{II}}$ molar concentration corresponding to $50 \mathrm{mM}$. An appropriate amount of $\mathrm{NaOH}(1 \mathrm{M})$ was then added to the mixture $\left(\mathrm{Fe}^{\mathrm{II}} / \mathrm{Fe}^{\mathrm{III}}\right.$-oxyhydroxide) to provide the ratio $n\left(\mathrm{OH}^{-}\right) / n\left(\mathrm{Fe}^{\mathrm{III}}\right)=1$ where $n$ represents the number of moles. Such a quantity of $\mathrm{NaOH}$ was required to form stoichiometric magnetite (Reaction 1), thus the starting $\mathrm{pH}$ was very 
111 high ( 9.7). The expected transformation of $\mathrm{L}$ and $\mathrm{G}$ into magnetite can be achieved through

112 the following reaction:

$$
2 \mathrm{Fe}^{\mathrm{III}} \mathrm{OOH}+\mathrm{Fe}^{\mathrm{II}}+2 \mathrm{OH}^{-} \Rightarrow \mathrm{Fe}^{\mathrm{II}} \mathrm{Fe}^{\mathrm{III}}{ }_{2} \mathrm{O}_{4}+2 \mathrm{H}_{2} \mathrm{O}
$$

114 The suspensions were vigorously stirred for 1 hour, and then aged without stirring at room 115 temperature for 1 hour, 1 day and 1 month.

116 At specified aging time, the corresponding batch was withdrawn from the series, centrifuged 117 and the solid was dried in glove box for further analysis. To measure the aqueous 118 concentration of $\mathrm{Fe}^{\mathrm{II}}$ at each time point, aliquots were sampled from the batches, filtered 119 through $0.22 \mu \mathrm{m}$ filters and added to a tube that contained $2 \mathrm{~N} \mathrm{HCl}$. The $\mathrm{Fe}^{\mathrm{II}}$ concentration in 120 a given solution was determined colorimetrically by the ferrozine assay as previously reported

121 [31]. Total $\mathrm{Fe}^{\mathrm{II}}$ concentration was measured by performing the ferrozine assay after a full 122 dissolution of the suspension in a concentrated $\mathrm{HCl}$ acidic solution. The $\mathrm{pH}$ of the suspensions was also measured at each time point.

\subsection{Sample characterization}

125 Solid samples were analyzed by Mössbauer spectroscopy. BackscatteringMössbauer

126 spectroscopy using the miniaturized Mössbauer spectrometer MIMOS II [32]was employed to 127 determine the oxidation state of iron and the iron mineralogy of the samples. The filtered 128 samples were inserted into $\mathrm{a} \sim 3 \mathrm{~cm}^{2}$ holder specially designed to perform backscatter

129 Mössbauer analyses at room temperature. Reemitted backscattered $\gamma$-rays $(14.4 \mathrm{keV})$ were 130 selected by four Si-PIN-diodes detectors. Centre shifts $C S$ were reported with respect to that 131 of $\alpha-\mathrm{Fe}$ at room temperature. Mössbauer spectra were computer-fitted with either a sum of 132 Lorentzian shape lines or a Voigt profile analyses [33]. 
133 Transmission electron microscopy (TEM) observations were carried out with a Philips CM20

134 TEM (200 kV) coupled with an EDX energy dispersive X-ray spectrometer. The solid powder 135 was re-suspended in $2 \mathrm{~mL}$ ethanol under ultrasonication, and a drop of suspension was 136 evaporated on a carbon-coated copper grid which was placed on filter paper.

137 The specific surface area of synthesized solids was determined by multipoint $\mathrm{N}_{2}$-BET analysis 138 using a Coulter (SA 3100) surface area analyzer and was found to be 190,59 and $38 \mathrm{~m}^{2} \mathrm{~g}^{-1}$ 139 for $\mathrm{F}, \mathrm{L}$ and $\mathrm{G}$ respectively.

\section{RESULTS AND DISCUSSION}

\subsection{Initial ferric oxyhydroxides}

143 The Mössbauer spectroscopy was used to characterize ferric oxyhydroxides ( $F$, L and $G$ ).

144 Hyperfine parameters corresponding to their spectra recorded at room temperature (Fig. 1) are

145 reported in Table 1 . The $\mathrm{F}$ and $\mathrm{L}$ displayed typical Fe $\mathrm{F}^{\mathrm{III}}$ paramagnetic doublet and $\mathrm{G}$ spectrum 146 consisted of a sextet with asymmetrically broadened lines corresponding to a magnetically 147 ordered goethite.

148 Morphology of initial ferric oxyhydroxides is displayed by TEM images (Fig. S1) where F

149 particles are very small and heavily aggregated. The L crystals are lath-like and elongated 150 with gradually tapering ends like spindles. The length of the crystals is almost homogeneous 151 and varies between 200-300 $\mathrm{nm}$. Crystal needle shapes were identified for G. These crystals 152 vary between 300 and $400 \mathrm{~nm}$ in length.

\subsection{Transformation products}


156 The Mössbauer spectra of resulting products obtained by abiotic transformations of initial

157 ferric oxyhydroxides are shown (Fig. 2) along with hyperfine parameters (Table 1). Magnetite

158 formation was quantified after specified aging times of 1 hour, 1 day and 1 month.

159 Stoichiometric magnetite $\left(\mathrm{Fe}^{\mathrm{II}} \mathrm{Fe}^{\mathrm{III}}{ }_{2} \mathrm{O}_{4}\right)$ at room temperature (RT) has a spinel structure

160 whose Mössbauer spectrum at RT is constituted by a superposition of two subspectra

161 associated with the distribution of the iron in the octahedral (B) and tetrahedral (A) sites

162 represented by $S_{B}$ and $S_{A}$ respectively. The two valence states on octahedral sites are not

163 distinguishableabove the Verwey transition $(125 \mathrm{~K})$ due to a fast electron hopping between

$164 \mathrm{Fe}^{\mathrm{II}}$ and $\mathrm{Fe}^{\mathrm{III}}$ in octahedral sites [34, 35]. The different Mössbauer spectra (Fig. 2) are

165 presented here to show the transformation of ferric oxyhydroxides into magnetite at each time

166 point. It was easy to distinguish the appearance of magnetite sextets (S) produced from $\mathrm{F}$ and

167 L substrates as both are characterized by doublets (D) in Mössbauer spectra at RT. In contrast,

$168 \mathrm{G}$ at the same temperatureis characterized by magnetically ordered component that consist of

169 a sextet with lines that are asymmetrically broadened. The value of $G$ magnetic hyperfine

170 field at room temperature $(\sim 378 \mathrm{kOe})$ [34]is much lower than the one obtained for sextets $\mathrm{S}_{\mathrm{A}}$

171 and $\mathrm{S}_{\mathrm{B}}$ of magnetite ( 490 and $460 \mathrm{kOe}$ respectively; see Table 1).

172 The Mössbauer spectra of the F-M transformations are shown in Fig. 2a. After 1 hour of 173 reaction, a doublet is present in the center of spectrum which reveals the presence of 174 untransformed $\mathrm{F}$, along with magnetic sextets corresponding to a spinel (magnetite). The 175 relative abundance of doublet decreases with the increase in time (Fig. 2a). The magnetic 176 components are very broad and the spectrum is fitted with a distribution of sextets. The 177 broadening of sextets probably corresponds to the crystal growth of a poorly crystallized 178 magnetite. These sextets become more resolved and narrow as the time proceeds from 1 hour 
to 1 month that could be linked to the increase in the crystallinity of magnetite. Therefore,

180 only two sextets $S_{A}$ and $S_{B}$ are used to fit the spectrum after 1 month. Same trend is observed 181 in case of L (Fig. 2b), except that the transformation extent is lower. The sextets corresponding to magnetite are also more resolved and narrow as compared to magnetite formed from F. No other intermediate minerals are observed during magnetite formation.

The Mössbauer spectra of the G-M transformation exhibit a different trend, in particular in the initial step of the reaction (Fig 2c, G-1 hour). The spectrum is constituted by the sextet $\mathrm{S}_{\mathrm{G}}$ of untransformed goethite and two additional components: (i) sextet $\mathrm{S}_{\mathrm{A}}(H=491 \mathrm{KOe})$ and (ii) a $\mathrm{Fe}^{\mathrm{III}}$ paramagnetic doublet $\left(\Delta=0.71 \mathrm{mms}^{-1}\right)$. These two last components are attributed to the initial growth of nanocrystalline magnetite, which could be described as the early stages of spinel phase formation on the goethite surface. Indeed, traces of magnetite was also observed by XRD analyses (Fig S2). Small crystal size of magnetite may induce drastic changes in the Mössbauer spectrum (Fig 2c, G-1 hour) which reveals distinct components when compared to

192 the spectrum of the initial goethite (Fig 1). We observe the appearance of a paramagnetic 193 doublet $\mathrm{D}$ in the center and a sextet $\mathrm{S}_{\mathrm{A}}$ which is superimposed upon those of $\mathrm{S}_{\mathrm{G}}$ butwith a 194 magnetic hyperfine field much larger than the one obtained for goethite. The doublet D 195 resembles that of many other paramagnetic $\mathrm{Fe}^{\mathrm{III}}$ bearing species and is therefore generally not applicable for identification of a spinel phase. However, the concomitant presence of doublet

$197 \mathrm{D}$ and sextet $\mathrm{S}_{\mathrm{A}}$ similar to that obtained for iron in the tetrahedral site of the spinel inverse 198 structure indicate the presence of nanocrystalline magnetite should not be excluded. This 199 observation could explain consequently the spectral behavior which reveals the collapse of 200 magnetic ordering in octahedral sites governed by a superparamagnetic relaxation [36]. These 201 results could be interpreted by adsorbed $\mathrm{Fe}^{\mathrm{II}}$ species transforming themselves into growing epitaxial nano-magnetite layer with magnetically short-range ordering. Doublet $\mathrm{D}$ could be 203 attributed to $\mathrm{Fe}^{\mathrm{III}}$ species formed by an electron transfer between adsorbed $\mathrm{Fe}^{\mathrm{II}}$ species and 
$204 \mathrm{Fe}^{\mathrm{III}}$ species present on the goethite surface. Such $\mathrm{Fe}^{\mathrm{II}}-\mathrm{Fe}^{\mathrm{III}}$ exchange was clearly 205 demonstrated by Williams et al. [37], by using the isotope specificity of ${ }^{57} \mathrm{Fe}$ Mössbauer 206 spectroscopy. Increasing the aging time (1 day to 1 month) enhances the spinel ordering as 207 confirmed by the vanishing of doublet D and the appearance of the classical magnetic 208 components $\left(\mathrm{S}_{\mathrm{A}}\right.$ and $\left.\mathrm{S}_{\mathrm{B}}\right)$. Sextets of magnetite are now clearly resolved and the partial 209 conversion of goethite proceeds by solid-state reaction [17].

210 All these results consistently show that the $\mathrm{F}$ was more reactive to transform into magnetite. 211 Almost $90 \%$ of $\mathrm{F}$ was transformed into magnetite after aging time of $1 \mathrm{~h}$, as compared to $75 \%$ 212 of L and $11 \%$ of G. After 1 month, almost whole of F and L was transformed (Table 2). Large 213 amount $(\sim 70 \%)$ of $\mathrm{G}$ was transformed into magnetite after 1 month, although, goethite is one 214 of the highly stable oxides. The order of reactivity can be classified as F > L > G, which is 215 consistent with previous findings [22]. Pedersen et al. reported that the transformation extent 216 decreases by approximately one order of magnitude going from ferrihydrite to lepidocrocite to 217 goethite and the main control on the transformation yield appears to be affiliated with the 218 properties and crystallinity of the iron oxide mineral. This order of reactivity found in present 219 work $(\mathrm{F}>\mathrm{L}>\mathrm{G})$ is in accordance with surface area, solubility, thermodynamic stability and 220 dissolution data previously reported in literature [22, 23, 38-40]. Size and order of crystal are 221 important determinative factors, affecting dissolution rate of iron oxides as ferrihydrite, an 222 unstable Fe oxide with a large specific surface is more soluble, whereas crystallized iron 223 oxides such as goethite are thermodynamically stable with a relatively low dissolution rate $224[22,23,40]$. 
228 The degree of stoichiometry $(\delta)$ of magnetite $\mathrm{Fe}_{3-\delta} \mathrm{O}_{4}$ was quantitatively determined by using 229 the Mössbauer data obtained during transformations (Table 1). The stoichiometry is defined 230 by $x=\mathrm{Fe}^{\mathrm{III}} /\left(\mathrm{Fe}^{\mathrm{II}}+\mathrm{Fe}^{\mathrm{III}}\right)$ where $0.67 \leq x \leq 1$ with stoichiometric magnetite corresponding to $231 x=0.67$ and $\delta=0$. Stoichiometry of magnetite was calculated as a function of aging time 232 from experimental values of relative areal (RA) of both sextets, $S_{A}$ and $S_{B}$, as explained by 233 Zegeye et al.[9]. Because Mössbauer spectroscopy was not always able to detect 234 unambiguously the presence of low amount of hematite $(<10 \mathrm{wt} \%)$ in the presence of 235 magnetite [41], XRD was used to confirm the absence of $\alpha \mathrm{Fe}_{2} \mathrm{O}_{3}$ in the final products (Figure 236 S2). A slight departure from stoichiometry was observed for final magnetite obtained from $\mathrm{F}$ $237(\delta \sim 0.04)$ and $\mathrm{L}(\delta \sim 0.05)$ after 1 month. Magnetite formed from $\mathrm{G}$ was the least 238 stoichiometric as the transformation was not fully accomplished. A higher departure $(\delta \sim 0.2)$ 239 was observed for $\mathrm{G}$ product after 1 day that evolved towards lower value $(\delta \sim 0.08)$ in 1 240 month. On the contrary to magnetite formed from G, slight increase in departure from 241 stoichiometry of magnetite $(\delta=0.005-0.05)$ in L product was observed with an increase in 242 aging time. Stoichiometric magnetite $(\delta=0)$ was not obtained in any of the final product regardless of initial ferric oxyhydroxide, although, the stoichiometric conditions were 244 imposed in the initial suspension. It suggests that small part of the initial soluble $\mathrm{Fe}^{\mathrm{II}}$ did not 245 incorporate in the final solid product leading to a non-stoichiometric magnetite. Similarly it 246 was reported elsewhere that excessive washing of stoichiometric magnetite caused the 247 magnetite to become oxidized due to $\mathrm{Fe}^{\mathrm{II}}$ dissolution [7, 8]. On the other hand, biogenic 248 magnetite was stoichiometric with $\delta \sim 0$ when the mineralogical transformation of $\mathrm{L}$ was 249 investigated in a Shewanella putrefaciens culture under anaerobic conditions using 250 methanoate as the electron source for almost 1 month [9]. Thus, stoichiometry of final 251 magnetite could vary according to the nature of initial ferric oxyhydroxide, aging time and the pathway of magnetite formation. Stoichiometric magnetite may form directly by 
coprecipitation [14] or bioreduction of lepidocrocite [9], while topotactic formation from ferric oxyhydroxide leads to non-stoichiometric phases. Stoichiometry of magnetite is an important characteristic as it can influence its reactivity.

\subsubsection{Evolution of $\mathrm{pH}$ and concentration of soluble $\mathrm{Fe}^{\mathrm{II}}$}

Total and soluble $\mathrm{Fe}^{\mathrm{II}}$ concentration, $\mathrm{pH}$ in the oxide suspensions at specified aging times during transformation process are reported in Table 2. The $\mathrm{pH}$ at the start of reaction was almost same for F, L and $\mathrm{G}(\sim 9.7)$. This value is significantly higher than the $\mathrm{pH}$ of precipitation $(\sim 7)$ of $\mathrm{Fe}(\mathrm{OH})_{2}$ corresponding to the initial $\mathrm{Fe}^{\mathrm{II}}$ concentration. As the reaction proceeded, a decrease in $\mathrm{pH}$ was observed as the $\mathrm{OH}^{-}$species were consumed to form magnetite as shown in reaction (1). Decrease in $\mathrm{pH}$ could positively be correlated to the dissolution of the initial $\mathrm{Fe}(\mathrm{OH})_{2}$ precipitates into hydroxylated $\mathrm{Fe}^{\mathrm{II}}$ species adsorbed on the ferric oxyhydroxides. After 1 month, the $\mathrm{pH}$ observed for $\mathrm{F}$ and L suspension was $~ 5.5$ while $\mathrm{pH}$ was higher $(\sim 7.5)$ for partially transformed $\mathrm{G}$. The total $\mathrm{Fe}^{\mathrm{II}}$ concentration of the final suspension (transformation product and solution) was measured during experiment and it was almost the same as the initial concentration $(50 \mathrm{mM})$ suggesting the absence of $\mathrm{Fe}^{\mathrm{II}}$ oxidation (Table 2). On the other hand, concentration of soluble iron was very low after 1 hour of aging time. Almost $98 \%$ of the input $\mathrm{Fe}^{\mathrm{II}}$ amount was rapidly removed from the aqueous solution although the extent of transformation of $\mathrm{F}, \mathrm{L}$ and $\mathrm{G}$ was different. It is probably due to sorption of $\mathrm{Fe}^{\mathrm{II}}$ species on iron oxide surface as reported elsewhere $[25,38]$. In this case, $\mathrm{Fe}^{\mathrm{II}}-$ to-Fe ${ }^{\mathrm{III}}$ electron transfer and precipitation processes are contributing to the observed sorption phenomena. These observations are consistent with literature [40] stating that the $\mathrm{Fe}^{\mathrm{II}}$ adsorption edge was the same for the three oxyhydroxide phases: goethite, hematite and ferrihydrite. At $\mathrm{pH}>7.5$, the adsorption of $\mathrm{Fe}^{\mathrm{II}}$ onto iron oxyhydroxide phases reach $100 \%$ 
regardless of the tested oxide. Calculations using PHREEQC2 [42] of the pH dependence of adsorption of $\mathrm{Fe}^{\mathrm{II}}$ on $\mathrm{F}$, L or $\mathrm{G}$ confirms that all $\mathrm{Fe}^{\mathrm{II}}$ is adsorbed at a $\mathrm{pH}$ higher than 7 . A progressive release of $\mathrm{Fe}^{\mathrm{II}}$ in solution $(\sim 5-8 \mathrm{mM})$ was observed during the formation of magnetite from $\mathrm{F}$ and $\mathrm{L}$ when the $\mathrm{pH}$ reached a value lower than 7 (Table 2). This phenomenon could be attributed to a progressive desorption of previously sorbed $\mathrm{Fe}^{\mathrm{II}}$ species. After 1 month of aging time, the transformation extent of $\mathrm{F}$ and $\mathrm{L}$ was very close to $100 \%$ (Table 1). The departure from stoichiometry of the obtained magnetite is $\delta \sim 0.04$, its chemical composition is therefore $\mathrm{Fe}^{\mathrm{III}}{ }_{2.08} \mathrm{Fe}^{\mathrm{II}}{ }_{0.88} \mathrm{O}_{4}\left(\mathrm{Fe}^{\mathrm{II}}: \mathrm{Fe}^{\mathrm{III}}\right.$ of 2.36 instead of 2 for $\left.\delta \sim 0\right)$. By considering that all the initial $\mathrm{Fe}^{\mathrm{III}}$ species $(100 \mathrm{mM})$ were present inside the magnetite, 42.4 $\mathrm{mM}$ of $\mathrm{Fe}^{\mathrm{II}}$ are taking part in the formation reaction. Therefore, a concentration of $7.6 \mathrm{mM}$ of unreacted $\mathrm{Fe}^{\mathrm{II}}$ species is expected, which is in good agreement with that measured in solution after 1 month of reaction for $\mathrm{F}$ and $\mathrm{L}$ (Table 2). On the other hand, $\mathrm{pH}$ was still higher than 7 after one month of $\mathrm{G}$ transformation therefore soluble $\mathrm{Fe}^{\mathrm{II}}$ was almost negligible.

\subsubsection{Morphological properties of transformation products}

The morphology of the particles produced is available to clarify the transformation of ferric oxyhydroxides into magnetite as shown by transformation products after 1 month (Fig. 3). TEM findings were consistent with Mössbauer results. Variations in size and shape of magnetite particles were observed among the products of tested ferric oxyhydroxides. Magnetite particles resulting from F transformation (Fig. 3, F-1 month) were smaller with non-uniform size or shape. The shape of magnetite particles was between hexagonal to octahedral in the transformation products of both $\mathrm{G}$ and $\mathrm{L}$ substrates (Fig. 3, G-1month, L1month). TEM images showed that there was still large amount of $G$ which was not transformed into magnetite, while traces of $\mathrm{L}$ were also visible. A difference in morphology 
and particle size of generated magnetite was observed dependent on the nature of initial substrates. Indeed, the transformation of ferrihydrite produced small magnetite particles $(<50$ $\mathrm{nm}$ ) while those found in the transformation products of $\mathrm{L}$ or $\mathrm{G}$ have larger particles (magnetite particles with $70-80 \mathrm{~nm}$ and $200-300 \mathrm{~nm}$ in $\mathrm{L}$ and G products respectively). It seems that magnetite, formed by reaction with $\mathrm{Fe}^{\mathrm{II}}$, has morphology and particle size similar to those of the initial oxyhydroxides which occurs in topotactic conversion of initial compounds to magnetite $[14,43]$. In addition, the Mössbauer spectra of magnetite formed from ferrihydrite displays broad lines, often caused by a structural disorder. This observation is also in favor of a topotactic formation of magnetite onto poorly crystallized ferrihydrite. In contrast, well ordered magnetite with sharp Mössbauer lines was obtained from crystallized iron oxides (i.e. L and G) (Fig. 2\&3).

Since final product of $\mathrm{G}$ transformation is a mixture of goethite and magnetite, only magnetite produced from $\mathrm{F}$ and $\mathrm{L}$ were characterized by $\mathrm{N}_{2}$ adsorption isotherm. The specific surface area (SSA) experimental value of magnetite, formed from $\mathrm{F}$ or $\mathrm{L}$, determined by the BET method was found to be $40 \pm 2$ and $20 \pm 2 \mathrm{~m}^{2} \mathrm{~g}^{-1}$, respectively. The radius of the supposed spherical particles (the density of magnetite, $\rho=5.15 \times 10^{6} \mathrm{~g} / \mathrm{m}^{3}$ ) can be related to the surface area as $\mathrm{A}=6 /(\rho . d)$. Thus, the calculated average diameter of a supposed spherical particle is $\sim 30 \mathrm{~nm}$ and $\sim 60 \mathrm{~nm}$ for magnetite from $\mathrm{F}$ for L respectively, which is consistent with the average size estimated by the TEM observations. The size of magnetite particles in F product falls in the size range of nano-particles of magnetite observed for commercially available nano-magnetite (i.e. $48 \mathrm{~m}^{2} \mathrm{~g}-1,30 \mathrm{~nm}$ ) [44].

\section{CONCLUSION}


The transformation of ferric oxyhydroxides into magnetite was investigated in the present

325 work which contributes to our understanding of the magnetite formation in natural

326 environments. Order of reactivity to transform into magnetite was F > L > G. The evolution of

327 stoichiometry of final magnetite was also monitored. This study demonstrates that the

328 transformation of ferric oxyhydroxides in the presence of $\mathrm{Fe}^{\mathrm{II}}$ can be affected by many factors

329 including mineralogy of initial oxyhydroxide, aging time and solution chemistry. Magnetite

330 was the product, with variable stoichiometry, particle size and surface area, obtained from

331 different ferric oxyhydroxides. Magnetite was non-stoichiometric regardless of the initial

332 ferric oxyhydroxide although stoichiometric conditions were imposed. In the case of goethite,

333 it is more striking as observed by Mössbauer spectroscopy over aging time. The results

334 suggest a solid-state transformation of goethite into magnetite with an electron transfer

335 driving the spinel ordering between adsorbed $\mathrm{Fe}^{\mathrm{II}}$ and the ferric oxide. Moreover, reactivity of

336 the magnetite could be different depending on its source of ferric mineral which need to be

337 explored for remediation purposes. For example, magnetite produced from ferrihydrite was

338 more close to stoichiometry with smaller particles and higher surface area; all these factors

339 could possibly contribute towards its high reactivity. $\mathrm{Fe}^{\mathrm{II}}$-induced transformations of ferric

340 oxyhydroxides could be a novel way to synthesize nano-sized particles of magnetite. These

341 findings have important implications for remediation technologies using magnetite as catalyst,

342 and also for the natural attenuation of contaminants in soils and sediments.

\section{Acknowledgements}

344 The authors acknoweledge the financial support of Higher Education Commission of Pakistan

345 (HEC), Agence Nationale de la Recherche (ANR) and Agence de l'Environnement et de la

346 Maitrise de l'Energie (ADEME) (Programme ECOTECH 2009, Production durable de

347 Technologies de l'Environnement, CERVEAU NP, décision attributive d'aide $\mathrm{n}^{\circ}$ 
348 0994C0103). We are also thankful to J. Ghanbaja for TEM analyses. We would like to thank

349 the Région Lorraine and the GISFI (Groupement d'Intérêt Scientifique sur les Friches 350 Industrielles) for financial support.

351 


\section{References}

353

354 [1] W. Stumm, B. Sulzberger, Geochim. Cosmochim. Acta, 56 (1992) 3233-3257.

355 [2] R.M. Cornell, U. Schwertmann, The Iron Oxides: Structure, Properties, Reactions, 356 Occurrence and Uses, Wiley-VCH, 1996.

357 [3] M. Elsner, R.P. Schwarzenbach, S.B. Haderlein, Environ. Sci. Technol. 38 (2003) 799$358 \quad 807$.

359 [4] K. Hanna, B. Rusch, L. Lassabatere, A. Hofmann, B. Humbert, Geochim. Cosmochim. 360 Acta, 74 (2010) 3351-3366.

361 [5] M. Abdelmoula, F. Trolard, G. Bourrié, J.M.R. Génin, Hyperfine Interact. 112 (1998) $362 \quad 235-238$.

363 [6] F. Trolard, J.M.R. Génin, M. Abdelmoula, G. Bourrié, B. Humbert, A. Herbillon, 364 Geochim. Cosmochim. Acta, 61 (1997) 1107-1111.

365 [7] C.A. Gorski, M.M. Scherer, Am. Mineral. 95 (2010) 1017-1026.

366 [8] C.A. Gorski, M.M. Scherer, Environ. Sci. Technol. 43 (2009) 3675-3680.

367 [9] A. Zegeye, M. Abdelmoula, M. Usman, K. Hanna, C. Ruby, Am. Mineral. 96 (2011) 368 1410-1413.

369 [10] E.J. Oloughlin, C.A. Gorski, M.M. Scherer, M.I. Boyanov, K.M. Kemner, Environ. Sci. 370 Technol. 44 (2010) 4570-4576.

371 [11] J.M. Zachara, R.K. Kukkadapu, J.K. Fredrickson, Y.A. Gorby, S.C. Smith, 372 Geomicrobiol. J. 19 (2002) 179-207.

373 [12] R.S. Cutting, V.S. Coker, J.W. Fellowes, J.R. Lloyd, D.J. Vaughan, Geochim. 374 Cosmochim. Acta, 73 (2009) 4004-4022.

375 [13] J.M.R. Génin, C. Ruby, A. Géhin, P. Refait, C. R. Geosci. 338 (2006) 433-446.

376 [14] E. Tronc, P. Belleville, J.P. Jolivet, J. Livage, Langmuir, 8 (1992) 313-319. 
[15] C.M. Hansel, S.G. Benner, S. Fendorf, Sci. Technol. 39 (2005) 7147-7153.

[16] Y. Tamaura, K. Ito, T. Katsura, J. Chem. Soc. Dalton. (1983) 189-194.

[17] C. Ruby, A. Géhin, M. Abdelmoula, J.-M.R. Génin, J.-P. Jolivet, Solid State Sci. 5 (2003) 1055-1062.

[18] H. Liu, M. Ma, M. Qin, L. Yang, Y. Wei, J. Solid State Chem. 183 (2010) 2045-2050.

[19] B.-H. Jeon, B.A. Dempsey, W.D. Burgos, Environ. Sci. Technol. 37 (2003) 3309-3315.

[20] H. Liu, H. Guo, P. Li, Y. Wei, J. Solid State Chem. 181 (2008) 2666-2671.

[21] T. Ishikawa, Y. Kondo, A. Yasukawa, K. Kandori, Corros. Sci. 40 (1998) 1239-1251.

[22] H.D. Pedersen, D. Postma, R. Jakobsen, O. Larsen, Geochim. Cosmochim. Acta, 69 (2005) 3967-3977.

[23] N. Yee, S. Shaw, L.G. Benning, T.H. Nguyen, Am. Mineral. 91 (2006) 92-96.

[24] H. Liu, P. Li, B. Lu, Y. Wei, Y. Sun, J. Solid State Chem. 182 (2009) 1767-1771.

[25] J.P. Jolivet, P. Belleville, E. Tronc, J. Livage, Clay. Clay Miner. 40 (1992) 531-539.

[26] M. Usman, K. Hanna, M. Abdelmoula, A. Zegeye, P. Faure, C. Ruby, Appl. Clay Sci. In Press (2011) DOI:10.1016/j.clay.2011.10.008.

[27] F.C. Voogt, T. Fujii, P.J.M. Smulders, L. Niesen, M.A. James, T. Hibma, Phys. Rev. B, 60 (1999) 11193-11206.

[28] U. Schwertmann, R.M. Cornell, Iron Oxides in the Laboratory: Preparation and Characterization, Wiley-VCH, New York, 2000.

[29] A. Olowe, P. Refait, J. Génin, Hyperfine Interact. 57 (1990) 2037-2043.

[30] H. Tamura, S. Kawamura, M. Hagayama, Corros. Sci. 20 (1980) 963-971.

[31] E. Viollier, P.W. Inglett, K. Hunter, A.N. Roychoudhury, P. Van Cappellen, Appl. Geochem. 15 (2000) 785-790.

[32] G. Klingelhöfer, B. Fegley Jr, R.V. Morris, E. Kankeleit, P. Held, E. Evlanov, O. Priloutskii, Planet. Space Sci. 44 (1996) 1277-1288. 
402 [33] D.G. Rancourt, J.Y. Ping, Nucl. Instrum. Meth. B, 58 (1991) 85-97.

403 [34] E. Murad, J.H. Johnston, Mössbauer Spectroscopy Applied to Inorganic Chemistry, 404 Plenum, New York, 1984.

405 [35] R.E.Vandenberghe, C.A. Barrero, G.M. Da Costa, E.Van San, E. De Grave, Hyperfine 406 Interact. $126(2000)$ 247-259.

407 [36]A. Hartridge, A. K. Bhattacharya, M. Sengupta, C. K. Majumdar, D. Das, S. N. 408 Chintalapudi, J. Magn. Magn. Mater. 176 (1997) L89-L92.

409 [37] A.G.B. Williams, M.M. Scherer, Environ. Sci. Technol. 38 (2004) 4782-4790.

410 [38] B. Lu, H. Guo, P. Li, H. Liu, Y. Wei, D. Hou, J. Solid State Chem. 184 (2011) 21394112144.

412 [39] U. Schwertmann, Plant Soil, 130 (1991) 1-25.

413 [40] E. Liger, L. Charlet, P. Van Cappellen, Geochim. Cosmochim. Acta, 63 (1999) 29394142955.

415 [41] M. Gotić, G. Goščec, S. Musić, J. Mol. Struct. 924 (2009) 347.

416 [42] D.L. Parkhurst, C.A.J. Appelo, U.S. Geo. Surv. Water-Resour. Invest. Rep. 1999, 994174259.

418 [43] J.K. Fredrickson, J.M. Zachara, D.W. Kennedy, H. Dong, T.C. Onstott, N.W. Hinman, 419 S.-m. Li, Geochim. Cosmochim. Acta, 62 (1998) 3239-3257.

420 [44] X. Zeng, K. Hanna, A.T. Lemley, J. Mol. Catal. A: Chem. 339 (2011) 1-7.

421

422

423 


\section{$424 \quad$ Figure captions}

425

426 Figure 1: Mössbauer spectra of original ferric oxyhydroxides, ferrihydrite (F), goethite $(\mathrm{G})$

427 and lepidocrocite (L). Hyperfine parameters corresponding to these spectra are presented in 428 Table 1.

429 Figure 2: Mössbauer spectra of the transformation products of (a) F-ferrihydrite, (b) L430 lepidocrocite and (c) G-goethite, obtained after aging time of 1 hour, 1 day and 1 month. 431 Hyperfine parameters corresponding to these spectra are presented in Table 1. The percentage 432 corresponds to the relative emission of the most intense lines.

433 Figure 3: Bright field TEM images showing the transformations products after an aging time 434 of 1 month where $M$ stands for magnetite, $\mathrm{L}$ for lepidocrocite and $\mathrm{G}$ for Goethite.

435

436 
Tables

Table 1:Mössbauer hyperfine parameters of the spectra presented in Figure 1 and Figure 3. $C S$ : centre shift with respect to metallic $\alpha$-Fe at room temperature; $\Delta$ : quadrupole splitting in the paramagnetic state or $\varepsilon$. quadrupole shift; $H$ : Hyperfine magnetic field; $R A$ : relative area and $\delta$ : departure from stoichiometry of non-stoichiometric magnetite $\left(\mathrm{Fe}_{3-\delta} \mathrm{O}_{4}\right)$ determined by classical Mössbauer analysis ( $\delta=0$ for stoichiometric magnetite, $\mathrm{Fe}_{3} \mathrm{O}_{4}$ ).

$* \delta$ calculation is possible only when fitting of magnetite spectrum is done with two sextets; $\mathrm{S}_{\mathrm{A}}$ and $\mathrm{S}_{\mathrm{B}}$.

\begin{tabular}{|c|c|c|c|c|c|c|}
\hline Sample & Component & $\begin{array}{c}C S \\
\left(\mathrm{~mm} \mathrm{~s}^{-1}\right)\end{array}$ & $\begin{array}{c}\Delta o r \varepsilon \\
\left(\mathrm{mm} \mathrm{s}^{-1}\right)\end{array}$ & $\begin{array}{c}H \\
(\mathbf{k O e}) \\
\end{array}$ & $\begin{array}{l}R A \\
(\%)\end{array}$ & $\begin{array}{c}\text { Stoichiometry } \\
\delta \\
\end{array}$ \\
\hline Ferrihydrite & $\mathrm{D}$ & 0.35 & 0.68 & - & 100 & - \\
\hline \multirow[t]{4}{*}{ F-1 hour } & $\bar{D}$ & 0.38 & 0.71 & - & 9 & \multirow{4}{*}{$*$} \\
\hline & S1 & 0.30 & 0.20 & 459 & 13 & \\
\hline & S2 & 0.42 & -0.07 & 430 & 68 & \\
\hline & S3 & 0.25 & 0.01 & 485 & 10 & \\
\hline \multirow[t]{4}{*}{ F-1 day } & $\mathrm{D}$ & 0.34 & 0.61 & - & 4 & \multirow{4}{*}{$*$} \\
\hline & S1 & -0.01 & 0.005 & 476 & 12 & \\
\hline & $\mathrm{S} 2$ & 0.346 & 0.02 & 407 & 59 & \\
\hline & S3 & 0.678 & 0.02 & 462 & 25 & \\
\hline \multirow[t]{3}{*}{ F-1 month } & $\mathrm{D}$ & 0.30 & 0.77 & - & 2 & \multirow{3}{*}{$\delta=0.04$} \\
\hline & $\mathrm{S}_{\mathrm{A}}$ & 0.27 & 0 & 479 & 40 & \\
\hline & $\mathrm{S}_{\mathrm{B}}$ & 0.64 & 0 & 444 & 58 & \\
\hline Goethite & $\mathrm{S}_{\mathrm{G}}$ & 0.38 & -0.13 & 351 & 100 & - \\
\hline \multirow[t]{3}{*}{ G-1 hour } & $\mathrm{D}$ & 0.39 & 0.72 & - & 7 & \multirow{3}{*}{$*$} \\
\hline & $\mathrm{S}_{\mathrm{G}}$ & 0.37 & -0.13 & 364 & 89 & \\
\hline & $\mathrm{S}_{\mathrm{A}}$ & 0.37 & 0 & 491 & 4 & \\
\hline \multirow[t]{3}{*}{ G-1 day } & $\overline{\mathrm{S}_{\mathrm{G}}}$ & 0.38 & -0.13 & 378 & 68 & \multirow{3}{*}{$\delta=0.23$} \\
\hline & $\mathrm{S}_{\mathrm{B}}$ & 0.64 & -0.02 & 460 & 7 & \\
\hline & $\mathrm{S}_{\mathrm{A}}$ & 0.32 & -0.004 & 491 & 25 & \\
\hline \multirow[t]{3}{*}{ G-1 month } & $\overline{S_{A}}$ & 0.31 & 0.008 & 491 & 32 & \multirow{3}{*}{$\boldsymbol{\delta}=\mathbf{0 . 0 8}$} \\
\hline & $\mathrm{S}_{\mathrm{B}}$ & 0.66 & -0.003 & 458 & 35 & \\
\hline & $\mathrm{S}_{\mathrm{G}}$ & 0.38 & -0.14 & 377 & 33 & \\
\hline Lepidocrocite & $\mathrm{D}$ & 0.48 & 0.54 & - & 100 & - \\
\hline \multirow[t]{3}{*}{ L-1 hour } & $\mathrm{D}$ & 0.39 & 0.56 & - & 26 & \multirow{3}{*}{$\delta=0.005$} \\
\hline & $\mathrm{S}_{\mathrm{A}}$ & 0.32 & 0.01 & 484 & 25 & \\
\hline & $\mathrm{S}_{\mathrm{B}}$ & 0.61 & -0.05 & 452 & 49 & \\
\hline \multirow[t]{3}{*}{ L-1 day } & $\mathrm{D}$ & 0.39 & 0.56 & - & 2 & \multirow{3}{*}{$\delta=0.045$} \\
\hline & $\mathrm{S}_{\mathrm{A}}$ & 0.33 & 0.006 & 488 & 47 & \\
\hline & $\mathrm{S}_{\mathrm{B}}$ & 0.63 & 0 & 453 & 51 & \\
\hline \multirow[t]{3}{*}{ L-1 month } & $\mathrm{D}$ & 0.40 & 0.53 & - & 2 & \multirow{3}{*}{$\delta=0.05$} \\
\hline & $\mathrm{S}_{\mathrm{A}}$ & 0.33 & 0.01 & 490 & 41 & \\
\hline & $\mathrm{S}_{\mathrm{B}}$ & 0.58 & -0.02 & 456 & 57 & \\
\hline
\end{tabular}


Table 2: Percentage of magnetite formation measured by Mössbauer spectroscopy and variousconcentrations measured in the supernatant.

\begin{tabular}{ccccc}
\hline Sample & $\begin{array}{c}\text { Magnetite } \\
\text { formation } \\
(\%)\end{array}$ & pH & $\begin{array}{c}\text { Total Fe }^{\text {II }} \\
\text { concentration } \\
{[\mathrm{mM}]}\end{array}$ & $\begin{array}{c}\text { Soluble Fe } \\
\text { concentration } \\
{[\mathrm{mM}]}\end{array}$ \\
\hline
\end{tabular}

Ferrihydrite

\begin{tabular}{lcccc}
\hline F- $t=0^{*}$ & - & 9.7 & - & \\
F-1 hour & 91 & 6.9 & 49 & Not detected \\
F-1 day & 96 & 6 & 48 & 2 \\
F-1 month & 98 & 5.6 & 49 & 8 \\
\hline
\end{tabular}

Goethite

\begin{tabular}{lcccc}
\hline G- $t=0^{*}$ & - & 9.8 & - & \\
G-1 hour & 11 & 8.4 & 47 & Not detected \\
G-1 day & 32 & 8.2 & 48 & Not detected \\
G-1 month & 67 & 7.5 & 49 & Not detected \\
\hline
\end{tabular}

$455 *$ The $\mathrm{pH}$ was measured just after the addition of $\mathrm{NaOH}$ into the $\mathrm{Fe}^{\mathrm{III}}-\mathrm{Fe}^{\mathrm{II}}$ suspension 456 
Figure 1:
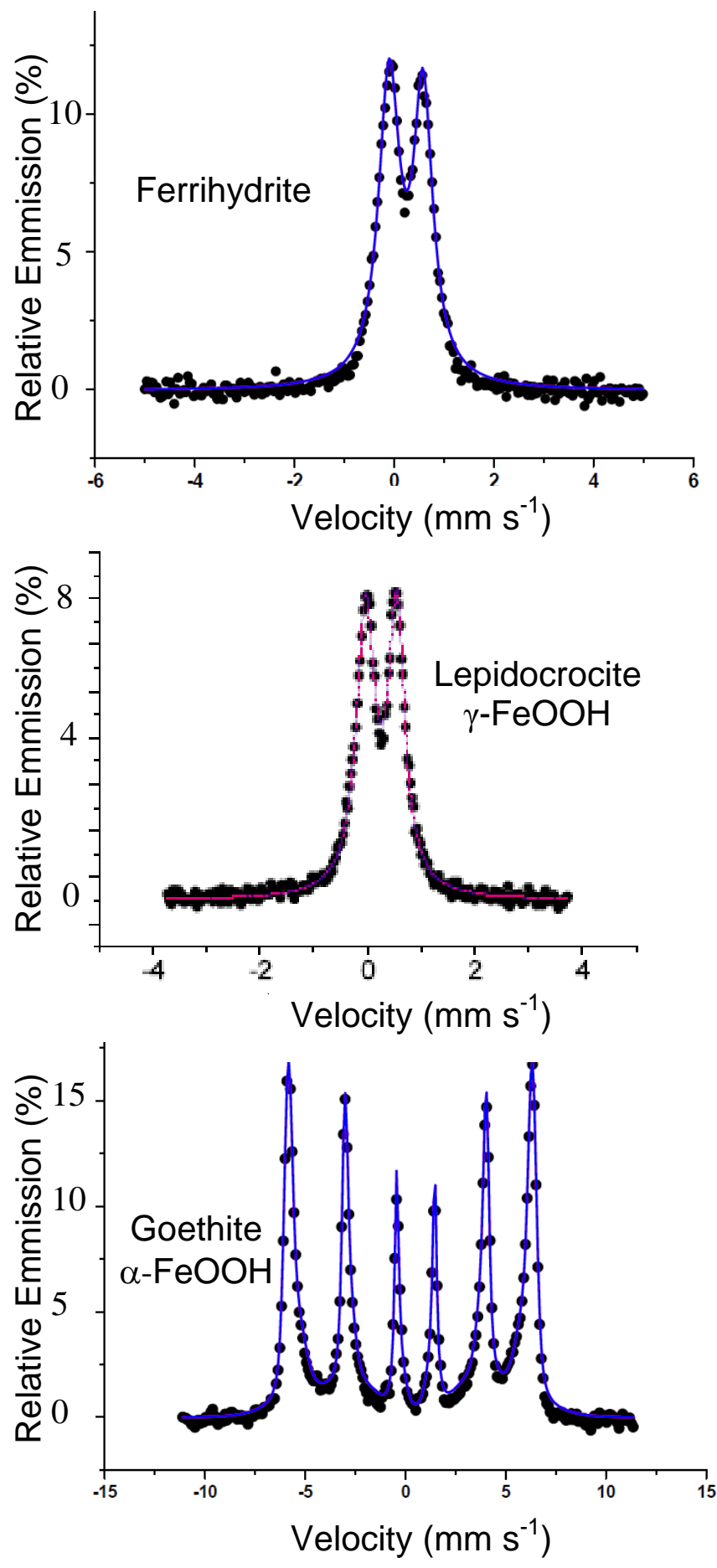
Figure 2:
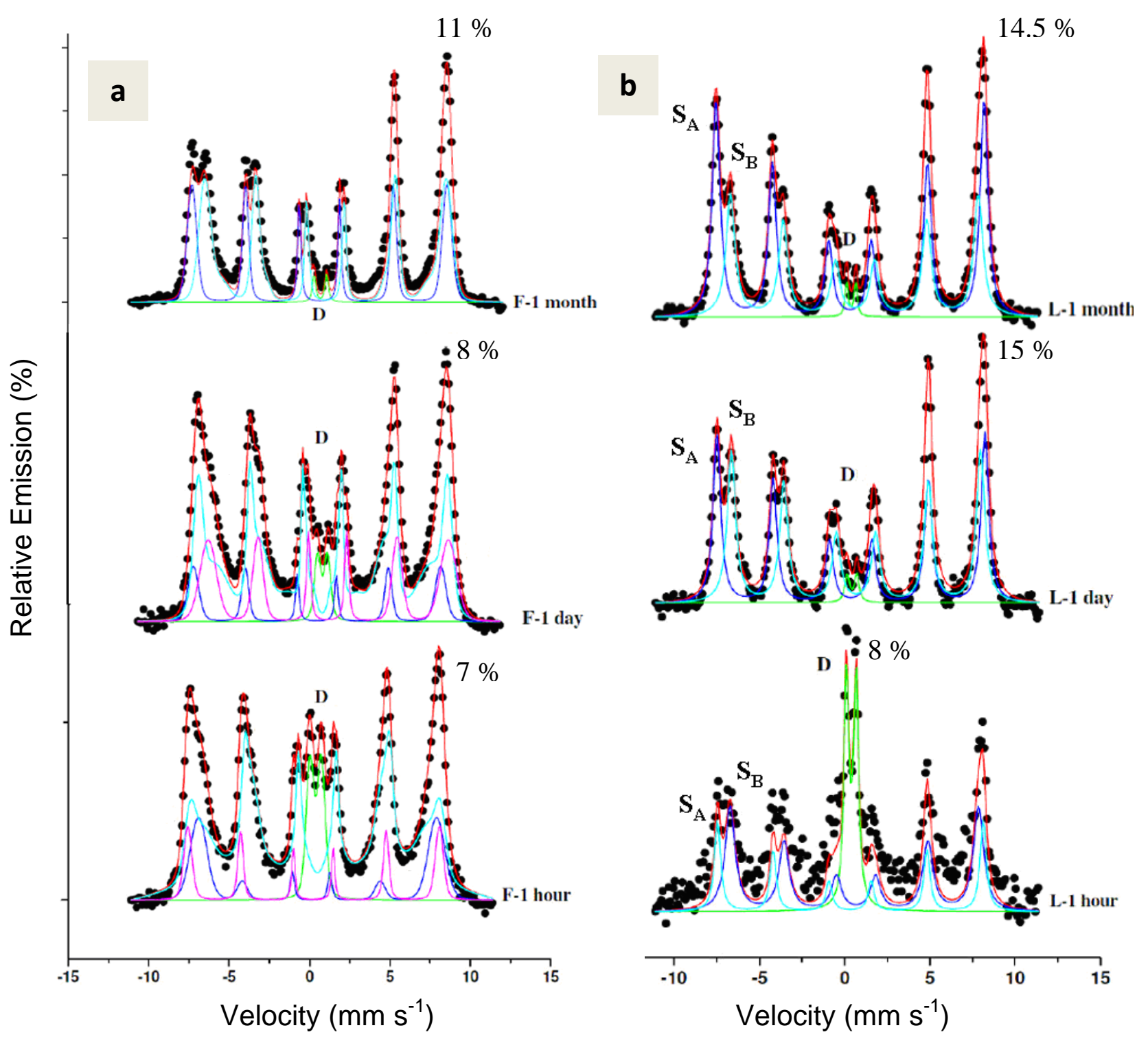


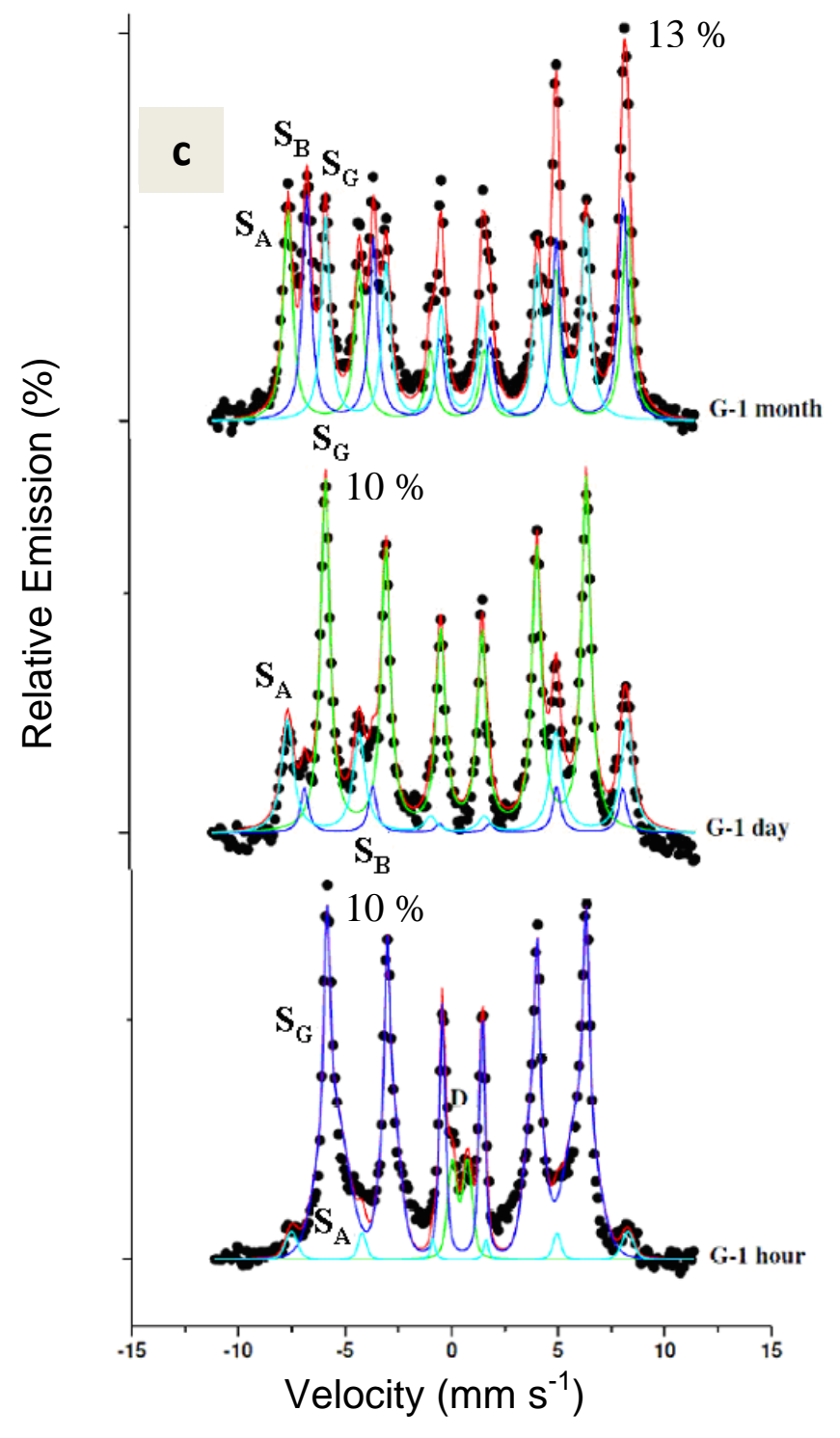


Figure 3:
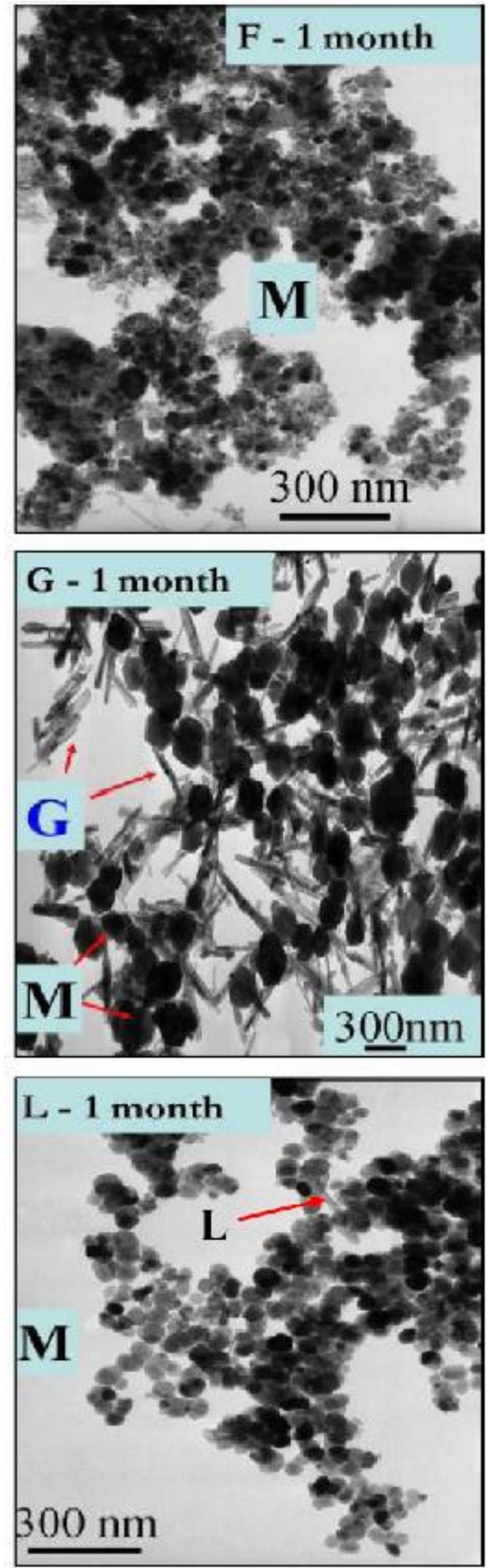

458 
462 Figure S1: Bright field TEM images showing initial ferric oxyhydroxides (F-ferrihydrite, L463 lepidocrocite and G-goethite).
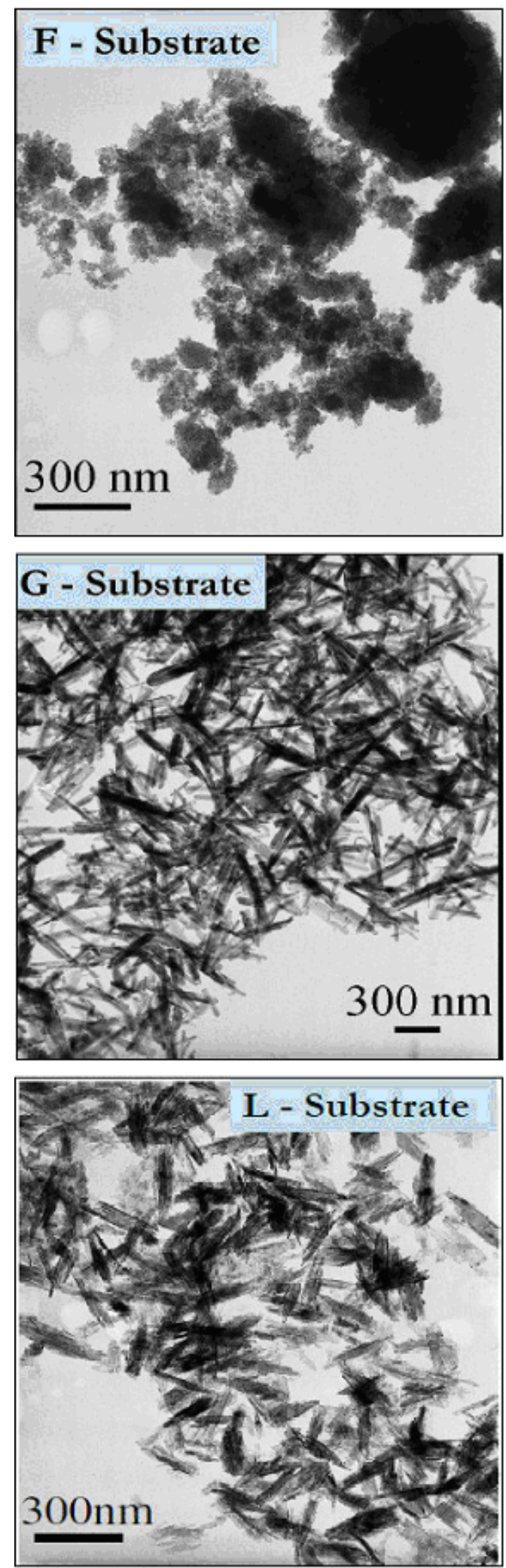
a
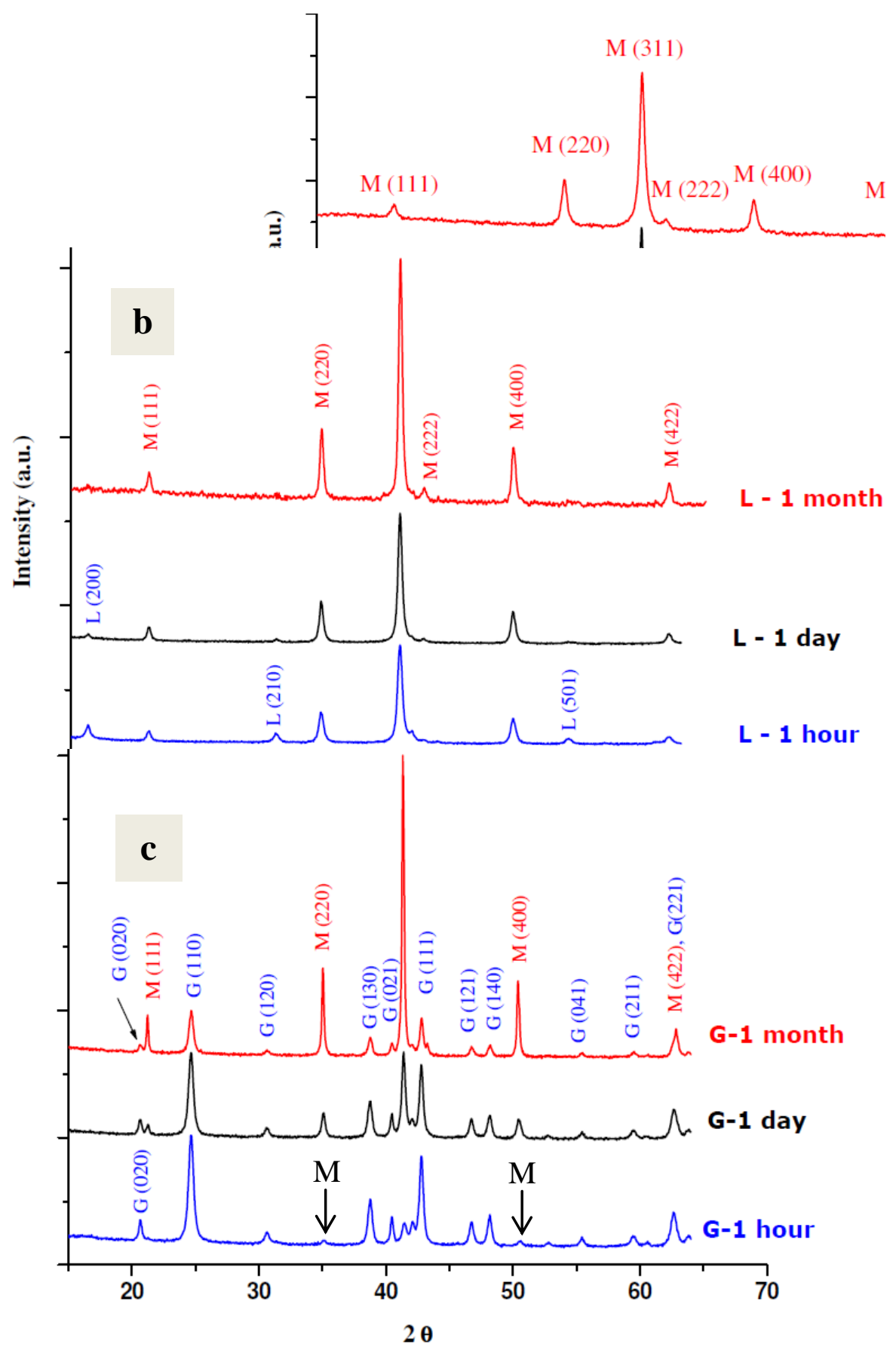
